\title{
Szkolne kasy oszczędności w okresie międzywojennym (1918-1939) w kontekście działań władz oświatowych
}

\begin{abstract}
School savings banks in the interwar period (1918-1939) in the context of the activities of educational authorities

The first school savings bank came into existence in Ghent, Belgium. It was founded by Francis Laurent in 1866. In Poland, the concept of saiving began to spread in the period of the National Education Commission, which recommended that children "practice thriftiness". Since the beginning of the 19th century, local attempts to establish school savings banks were undertaken in the Polish lands that had been divided in the partitions. The propagation of thrift developed on a broader scale only after regaining independence, especially after the economic reforms of 1924. The Ministry of Education recommended that teachers introduce various forms of thrift: organising school savings banks, talks and lectures about saving, celebration of Savings Day and promoting the idea in society as a whole. The interest in the propagation of thrift in education was expressed by the central and local education authorities by issuing various types of legal acts on this subject. The intensive development of school savings banks started in 1925. Until 1935, these organisations operated on cooperative principles. After 1935 they were held under the auspices of the Postal Savings Bank, which was dissolved in 1947. The state-owned Common Savings Bank was created in its place, whose supervision of school savings banks continues to this day and is a statutory duty of the bank. Thus, the interwar experience in the field of organising school savings banks was continued after the Second World War and is still being implemented in the contemporary educational reality.
\end{abstract}

Keywords: Keywords: history of education in Poland in the interwar period, school organisations, school savings banks, economic education.

Pierwsza szkolna kasa oszczędności (SKO) powstała w Belgii w Gandawie, którą założył w roku 1866 Franciszek Laurent w szkołach ludowych. Za przykładem Gandawy poszły inne miasta belgijskie, zakładające organizacje oszczędnościowe dla dzieci i młodzieży. W wieku XIX powstały szkolne kasy oszczędności w Szwecji, Anglii, Francji, Niemczech i Austrii. W Czechach oszczędność wśród młodzieży szkolnej była propago- 
wana przez Związek Ciułaczy Czeskich. Szkolne kasy oszczędności rozwijały się także w Ameryce Północnej, Brazylii, Australii, Japonii ${ }^{1}$.

W Polsce idee oszczędności zaczęto krzewić już za czasów Komisji Edukacji Narodowej, która zalecała „ćwiczyć dzieci w oszczędności”. Od początku XIX w. na ziemiach polskich pod zaborami podejmowano lokalne próby utworzenia szkolnych kas oszczędności. W Poznaniu zakładano tzw. złote skarbony, niewielkie instytucje finansowe, przeznaczone do odkładania przez dzieci i młodzież nawet niewielkich kwot i wdrażania $\mathrm{w}$ ten sposób do oszczędzania. Złote skarbony wydawały kartoniki do naklejania znaczków oszczędnościowych, przyozdobione herbem Poznania i napisem: „Za 3 marki można zdobyć aż 30 miast w Wielkopolsce" lub z innymi hasłami. Chodziło o naklejanie na kartonie znaczka za 10 fenigów z wizerunkiem miast Wielkopolski².

W Galicji idee oszczędności zaczął szerzyć w latach 70. XIX w. profesor gimnazjum Jerzy Harwot, który na walnym zgromadzeniu galicyjskiego Towarzystwa Pedagogicznego 21 lipca 1879 r. w Brodach wystąpił z referatem „Szkolne kasy oszczędności ze stanowiska pedagogii i ekonomii społecznej"3, ukazującym potrzebę budzenia zmysłu oszczędności w polskim społeczeństwie i organizowania szkolnych kas oszczędności dla dzieci i młodzieży. Dwadzieścia lat później, polski ekonomista Stanisław Stępiński wydał memoriał w sprawie tworzenia szkolnych kas oszczędności. W roku 1899 sprawa szkolnych kas oszczędności była przedmiotem rozważań drugiej konferencji dyrektorów szkół średnich we Lwowie. Pierwszą szkolną kasę oszczędności w Galicji założył w1906 r. profesor gimnazjum w Sokalu - Jan Piątek ${ }^{4}$. Jej statut zatwierdziła Rada Szkolna Krajowa. Podobne kasy zaczęły powstawać w Stryju, Brodach, Nowym Targu, Krakowie, Przemyślu, Tarnopolu, Kołomyi, Lwowie. Rada Szkolna Krajowa popierała tę akcję nauczycieli i od 1912 r. prowadziła w Małopolsce propagowanie oszczędności wśród młodzieży, wydając okólniki, polecające dyrektorom szkół średnich zakładanie szkolnych kas oszczędności5 . Od 1907 do 1911 r. na ogólną liczbę 139 szkół średnich tylko w 14 placówkach (9\%) powstały szkolne kasy oszczędności ${ }^{6}$. Przed odzyskaniem niepodległości publicystyka pedagogiczna poruszała zagadnienie szkolnych kas oszczęd-

1 S. Mandel, Szkolne Kasy Oszczędności jako czynnik społeczno-wychowawczy, Lwów 1913, s. 38-39.

2 Jak oszczędza młodzież w Polsce, „Gazetka Oszczędnościowa” 1932, nr 1, s. 8.

3 S. Mandel, op. cit., s. 27; J. Długokęcki, Jak zakładać i prowadzić szkolne kasy oszczędności, Warszawa 1931, s. 4.

${ }^{4}$ H. Kopia, Kasa oszczędności uczniów w gimnazjum sokalskim, „Muzeum” 1915, nr 1, s. 508; nr 2, S. 528 .

${ }_{5}$ Okólnik c. k. Rady Szkolnej Krajowej w sprawie szkolnych kas oszczędności, „Czasopismo dla Spółek Rolniczych” 1911, nr 10, s. 213-115. Por., Pouczenia o prowadzeniu groszowych kas oszczędności (dla młodzieży, służby domowej, gospodarczej, robotników i licznych rzesz ubogiej ludności), „Czasopismo dla Spółek Rolniczych" 1911, nr 2, s. 18-25.

6 J. Długokęcki, op. cit., s. 32-33. Por., F. Kułak, Szkolne Kasy Oszczędności w okręgu spółki oszczędnościowej i pożyczkowej w Kuszynie, „Czasopismo dla Spółek Rolniczych” 1910, nr 2, s. 45-50; Szkolne kasy oszczędności, „Czasopismo dla Spółek Rolniczych” 1911, nr 2, s. 25-28. 
ności, ukazując ich wartości wychowawcze i zasadność tworzenia wśród dzieci i młodzieży ${ }^{7}$.

Po latach zaborów i I wojny światowej problemy gospodarcze wysuwały się na pierwszy plan zagadnień społecznych i państwowych ${ }^{8}$. Na szerszą skalę propaganda oszczędności w szkolnictwie rozwinęła się dopiero po odzyskaniu niepodległości, a zwłaszcza po reformie gospodarczej z 1924 r. Do popularyzowania idei oszczędności w szkolnictwie przyczynił się zjazd dyrektorów państwowych gimnazjów w dniach 22-23 lutego 1925 r. w Warszawie, który wezwał nauczycieli do podjęcia propagandy oszczędności wśród młodzieży szkolnej, której należało wpajać umiejętności i zasady oszczędzania środków finansowych. Ponadto zjazd dyrektorów gimnazjów państwowych zwrócił się do Ministerstwa Wyznań Religijnych i Oświecenia Publicznego (WRiOP) o wyrażenie zgody i zalecenie organizowania szkolnych kas oszczędności na terenie wszystkich typów szkół ${ }^{9}$.

Te działania przyczyniły się do wydania 18 września 1925 r. przez Ministra WRiOP Stanisława Grabskiego okólnika, zalecającego organizowanie szkolnych kas oszczędności w porozumieniu z instytucjami oszczędnościowymi. S. Grabki, podkreślał znaczenie oszczędności. Wyjaśniał, że władze szkolne i liczne zastępy nauczycielstwa, świadome swych zadań i celów społecznych, winny baczna uwage poświęcić sprawie oszczędności wśród młodzieży. W akcji tej niezbędne będzie ścisłe porozumienie z instytucjami społecznymi, w których zakresie leży gromadzenie oszczędności, a które ciesza się zaufaniem ludności $i^{10}$. Minister zalecił nauczycielom różne formy propagowania oszczędności: organizowanie szkolnych kas oszczędności, pogadanek i wykładów o oszczędności, obchodów Dnia Oszczędności oraz propagowanie tej idei wśród całego społeczeństwa.

Zainteresowanie krzewieniem oszczędzania w szkolnictwie wyrażały centralne i terenowe władze oświatowe, wydając różnej treści rozporządzenia: w sprawie zakładania i organizowania szkolnych kas oszczędności, w sprawie propagandy oszczędności w szkołach, w sprawie Dnia Oszczędności. Zachęcały nauczycieli do zakładania szkolnych kas oszczędności, polecając następującą literaturę, zawierającą wskazania meto-

${ }^{7}$ R. Bolechowicz, Refleksje na temat kas oszczędności uczniów, „Znicz” II, 21; S. Jałomin, Szkolne kasy oszczędności, Kraków 1909, ss. 16; S. Jaromin, Szkolne kasy oszczędności w Krakowie, „Muzeum” 1910, nr 1, s. 523; S. Szyc, O wartości szkolnych kas oszczędności, „Rodzina i Szkoła” 1912, nr 3; S. Mandel, op. cit.; J. Majewski, Jaki system szkolnej kasy oszczędności byt najodpowiedniejszy, „Czasopismo Pedagogiczne” $1913, \mathrm{nr} 3$.

8 J. Czechowicz, Oszczędność - drogą do niezależności gospodarczej Polski, „Praca Szkolna” 1933/4, nr 2, s. 29-32.

9 S.E. Bońkowski, Szkolna Kasa Oszczędności, Warszawa 1926, s. 10. Poza tym oszczędność była propagowana i popularyzowana wśród całego społeczeństwa, któremu udowadniano, że jest ona podstawą dobrobytu państwa i metodą walki z kryzysem ekonomicznym przełomu lat 20. i 30. (A. Malarz, Jak osiagnać dobrobyt, Katowice-Warszawa 1931, ss. 24; R, Lenartowicz, Martwy a żywy pieniądz, Katowice 1932; Ks. J. Ma1kowicz, O oszczędności, Warszawa1934, ss. 32).

10 „Dz.U. MWRiOP” 1925, nr 15, s. 301-302. Okólnik ten był przedrukowywany na łamach wszystkich dzienników kuratoryjnych. Por. m. in., „Dz.U. Wydziału Oświecenia Publicznego Województwa Śląskiego” 1925, nr 11, s. 406-407; Dz.U. Kuratorium Okręgu Szkolnego (dalej: KOS) Brzeskiego" 1926, nr 9, s. 359-360. Por., Wskazania wychowawcze zawarte $w$ rozporządzeniach $i$ okólnikach Ministerstwa Wyznań Religijnych i Oświecenia Publicznego, zebrał F. Śliwiński, Łódź 1935, s. 48-49. 
dyczno - organizacyjne dla tych organizacji szkolnych: P. Załuski, Jak zakładać i prowadzić Szkolne Kasy Oszczędności (Warszawa 1926), S. E. Bońkowski, Szkolna Kasa Oszczędności, (Warszawa 1926), L. Twarecki, Spółdzielcze wychowanie młodzieży przez Szkolne Kasy Oszczędności (Lwów 1925) ${ }^{11}$. Polecana literatura zawierała regulaminy szkolnych kas oszczędności, przedstawiała zasady działania i prowadzenia rachunkowości SKO, systemy prowadzenia i sposoby przygotowania młodzieży do akcji oszczędzania oraz zasady organizacji Dnia Oszczędności. Ministerstwo WRiOP zatwierdziło publikację Piotra Załuskiego do użytku szkolnego, jako książkę dozwoloną do bibliotek szkół handlowych oraz jako pozycję pomocniczą dla nauczycieli wszystkich typów szkół ${ }^{12}$.

Mając na uwadze fakt, że ważną rolę w ekonomicznym podniesieniu społeczeństwa odgrywała szkoła, kolejny Minister WRiOP, Kazimierz Bartel, wydał w 1927 r. okólnik w sprawie propagandy oszczędności w szkołach, w którym szeroko uzasadniając znaczenie oszczędności dla jednostki, społeczeństwa i państwa, zwrócił się do dyrektorów szkół i nauczycieli o opracowanie szczegółowego programu pracy wychowawczej, mającej na celu propagandę wśród młodzieży zasad oszczędzania i czynne ich praktykowanie ${ }^{13}$. K. Bartel zaznaczywszy, że oszczędność jest cnotą mało znaną narodowi polskiemu, (o czym świadczyło bezmyślne niszczenie własnego, cudzego i wspólnego dobra, lekkomyślne wydawanie pieniędzy, beztroska i bezplanowość wydatków, brak przewidywania), nakazywał szkole kształtować takie cnoty, jak: zapobiegliwość, przezorność, oszczędność, praktyczność, które są charakterystyczne dla narodów silnych i potężnych, wysuwających się na czoło cywilizacji.

Do zadań szkoły minister K. Bartel włączył obowiązkową propagandę oszczędności, wyrażającą się nie tylko w oszczędzaniu pieniędzy, lecz także w poszanowaniu pracy, dbałości o czystość, porządek, ubiór, podręczniki i zeszyty, wyposażenie i sprzęt szkolny oraz w trosce o czystość i porządek klasy i szkoły. Już od najmłodszych lat należało rozwijać ducha oszczędności i wdrażać do działań oszczędnościowych w różnych zakresach życia: $w$ sumiennym i pilnym wypetnianiu obowiązków; szanowaniu zdrowia, sit i czasu swego i innych; szanowaniu cudzej własności, uprzejmości z ludźmi, poważania swego słowa; unikaniu nieładu i niedbalstwa w pracy $i$ gospodarstwie; cenieniu każdej rzeczy i przedmiotu, jeżeli posiada jakąś wartość; korzystaniu z udogodnień w dziedzinie wynalazków, jeżeli moga mieć zastosowanie pożyteczne w życiu gospodarczym; korzystaniu z rzeczy i rozrywek, które dają pożytek dla ducha i myśli naszej; przyuczaniu się do

\footnotetext{
${ }^{11}$ O zainteresowaniu publikacją P. Załuskiego świadczy fakt, że w 1932 r. ukazało się jej drugie wydanie. Por., „Dz.U. KOS Wołyńskiego” 1926, nr 5-6, s. 143-144; Okólnik Kuratora Okręgu Szkolnego Pomorskiego M. Pollaka z 12 stycznia 1932 roku w sprawie propagandy oszczędności $w$ szkołach, „Dz.U. KOS Pomorskiego" 1932, nr 1, s. 20-22.

12 Szkolne Kasy Oszczędności, „Głos Nauczycielski” 1934, nr 1, s. 25.

13 Okólnik Ministra WRiOP K. Bartla z dnia 8 stycznia 1927 roku, „Dz.U. MWRiOP” 1927, nr 3, s. 90-91. Por., „Dz.U. Wydziału Oświecenia Publicznego Województwa Śląskiego” 1927, nr 2, s. 32-34.
} 
robienia obrachunku i planu wydatków swoich; współdziałaniu i dopomaganiu sobie wzajemnie $w$ trudnościach życiowych ${ }^{14}$.

Ze względu na konieczność uporządkowania szkolnej akcji oszczędzania na terenie całego kraju Ministerstwo WRiOP zwołało w maju 1930 r. konferencję instytucji gospodarczych, zainteresowanych rozwojem szkolnych kas oszczędności. Zadaniem konferencji było wypracowanie zasad rozwoju szkolnej akcji oszczędnościowej. Ustalono ramowe regulaminy szkolnych kas oszczędności dla szkół powszechnych i średnich oraz regulamin instytucji oszczędzających, współpracujących ze szkolnymi kasami oszczędnościowymi ${ }^{15}$.

Wynikiem tej konferencji był wydany w 1930 r. przez Ministerstwo WRiOP kolejny okólnik skierowany do kuratorów, inspektorów, dyrektorów i kierowników szkół oraz wszystkich nauczycieli w sprawie ,rozwinięcia żywej i szerokiej akcji w kierunku organizowania i prowadzenia Szkolnych Kas Oszczędności”, której celem było pozyskanie dla idei oszczędności obecnych uczniów, w przyszłości czynnych obywateli Państwa, przyzwyczajenie ich do zasady oszczędzania, zapoznanie z pożytkiem i zadaniami pracy oraz zapoznanie z formami i metodami oszczędzania ${ }^{16}$.

Kolejny minister WRiOP, Sławomir Czerwiński, zalecał dostosowanie form i metod propagandy oszczędności do lokalnych warunków i potrzeb. Nauczycielom nakazywał zapoznawać uczniów z ideą oszczędzania podczas realizacji treści programowych nauki o Polsce współczesnej, języka polskiego, rachunków. Wychowankowie musieli mieć możliwość zapoznania się z praktyczną działalnością kas oszczędności, ich organizacją, sposobami prowadzenia, do czego nadawały się szkolne kasy oszczędności, w których uczniowie współdziałali jako członkowie zarządu, skarbnicy czy inkasenci. Minister zobowiązał się, że zaangażowanym w działalność szkolnych kas oszczędności nauczycielom ułatwi pracę, uwzględniając ulgi w obowiązkowym obciążeniu godzinowym i jednocześnie zapowiedział, że praca nauczyciela na polu oszczędności będzie brana pod uwage przy udzielaniu zapomóg, nagród i rozstrzyganiu różnorodnych konkursów. W ten sposób starał się zachęcić, a jednocześnie zmusić nauczycieli do wykazania aktywności w zakresie propagowania oszczędności w szkole. Ministerstwo zaleciło utworzenie przy kuratoriach specjalnych komisji, które miały koordynować akcję oszczędzania w szkolnictwie w całym okręgu. Zobowiązało terenowe władze szkolne do przedłożenia sprawozdań statystycznych i merytorycznych z dotychczasowych osiągnięć i planów na przyszłość w zakresie akcji oszczędzania przez dzieci i młodzież ${ }^{17}$.

14 J. Długokęcki, op. cit., s. 62. Por., J. Dominko, Oszczędzaj mądrze, „Młody Spółdzielca” 1936, nr 2 (7), s. 2; Pomóżmy sobie w biedzie, ibidem, s. 4-5; Umieć oszczędzać - to sztuka, „Młody Spółdzielca” 1937, nr 2 (8), s. 2.

15 J. Długokęcki, op. cit., s. 8-25.

${ }^{16}$ Okólnik Ministra WRiOP S. Czerwińskiego z 24 kwietnia 1930 roku w sprawie Szkolnych Kas Oszczędności, „Dz.U. MWRiOP” 1930, nr 5, s. 221-222. Por., „Dz.U. KOS Łódzkiego” 1930, nr 9, s. 201-202.

17 Okólnik Ministra WRiOP S. Czerwińskiego z 24 kwietnia 1930 roku w sprawie Szkolnych Kas Oszczędności s. 222-223; Okólnik Kuratorium Okręgu Szkolnego Łódzkiego w sprawie szkolnych kas oszczędności, „Dz.U. KOS Łódzkiego” 1931, nr 5, s. 94-95. 
W okresie międzywojennym wielką rolę w popularyzowaniu idei oszczędności odegrała Pocztowa Kasa Oszczędności (PKO), która już z końcem lat 20. zaczęła prowadzić zakrojoną na szeroką skalę propagandę oszczędzania wśród dzieci i młodzieży, popieraną przez Ministerstwo WRiOP. Dowodem jest fakt, że we wrześniu 1928 r. Ministerstwo WRiOP wydało dwa okólniki w sprawie propagandy oszczędności w szkołach, prowadzonej przez Pocztową Kasę Oszczędności, w którym zalecało udział w konkursie z nagrodami ogłoszonym przez PKO, polegającym na pisaniu wypracowań przez uczniów na tematy: Co wiesz o PKO?, Dlaczego należy oszczędzać? ${ }^{18}$ W 1934 r. Pocztowa Kasa Oszczędności opracowała statut, wskazówki organizacyjne oraz potrzebne druki dla szkolnych kas oszczędności. Materiały wysyłała zainteresowanym szkołom. Ponadto w swojej siedzibie w Warszawie zorganizowała wystawę, poświęconą szkolnym kasom oszczędności, na którą były zaproszone wycieczki szkolne w celu obejrzenia rezultatów akcji oszczędnościowej, prowadzonej w polskim szkolnictwie przez PKO. Wystawa była formą reklamy PKO i propagandy oszczędności ${ }^{19}$.

Celem nadania szkolnym kasom oszczędności jednolitej struktury organizacyjnej Ministerstwo WRiOP zatwierdziło w 1935 r. statuty tych organizacji szkolnych, rozwijających się w szkołach powszechnych, średnich ogólnokształcących i zawodowych, opracowane przez PKO. Statuty były dostosowane do poziomu rozwoju młodzieży poszczególnych szkół i dawały możliwość oparcia SKO na dowolnej instytucji oszczędnościowej, ze wskazaniem na Pocztową Kasę Oszczędności, której - jak podkreślano powszechność placówek umożliwiała współpracę każdej szkole ${ }^{20}$. Ministerstwo zatwierdziło dwa rodzaje statutów: „Statut Szkolnej kasy Oszczędności dla szkół powszechnych” oraz „Statut Szkolnej Kasy Oszczędności dla szkół średnich ogólnokształcących i zawodowych wszelkich stopni”. Cele i zakres działania szkolnej kasy oszczędności we wszystkich szkołach były jednakowe. Zgodnie ze statutem Szkolna Kasa Oszczędności ma na celu krzewienie zmystu oszczędności wśród młodzieży szkolnej $i$ w jej środowisku oraz przyzwyczajanie swoich członków do składania nawet najdrobniejszych kwot na szkolna książeczkę oszczędnościową ${ }^{21}$.

18 Okólnik Ministra WRiOP S. Czerwińskiego z 3 września i z dnia 18 września 1928 roku, „Dz.U. KOS Łódzkiego" 1928, nr 9, s. 156-7; Okólnik Kuratorium Okręgu Szkolnego Wołyńskiego w sprawie propagandy PKO w szkołach na rzecz idei oszczędności, „Dz.U. KOS Wołyńskiego” 1928, nr 8, s. 260-162; Propaganda Pocztowej Kasy Oszczędności w szkołach na rzecz idei oszczędności, „Dz.U. KOS Poznańskiego” 1928, nr 12, s. 175-177; „Dz.U. KOS Brzeskiego” 1928, nr 7, s. 356-360; „Dz.U. KOS Wileńskiego” 1933, nr 4, s. 163-164; „Dz.U. KOS Pomorskiego” 1933, nr 3, s. 98.

${ }_{19}$ Okólnik KOS Warszawskiego nr 334 z dnia 27 września 1934 roku w sprawie akcji oszczędzania, w: AAN, zespół: SIN, sygn. 11. Por., „Dz.U. KOS Wołyńskiego” 1934, nr 10, s. 494-495.

${ }^{20}$ Okólnik Ministra WRiOP Wacława Jędrzejewicza z dnia 14 stycznia 1935 roku w sprawie Szkolnych Kas Oszczędności, „Dz.U. MWRiOP” 1935, nr 1, s. 4.

${ }_{21}$ Statut Szkolnej Kasy Oszczędności dla szkół powszechnych, „Dz.U. MWRiOP” 1935, nr 1, s. 4-7; Statut Szkolnej Kasy Oszczędności dla szkół średnich ogólnokształcących i zawodowych wszelkich stopni, ibidem, s. 8-10. Statuty szkolnej kasy oszczędności były przedrukowywane w kuratoryjnych dziennikach urzędowych, m. in.: „Dz.U. KOS Poznańskiego” 1935, nr 3, s. 69-75; „Dz.U. KOS Warszawskiego” 1935, nr 3-4, s. 84-247; „Dz.U. KOS Krakowskiego” 1935, nr 1-2, s. 6, „Dz.U. KOS Poznańskiego” 1935, nr 2, s. 25. 
Zakres działalności SKO obejmował przyjmowanie wkładów oszczędnościowych od swoich członków, wydawanie im książeczek oszczędnościowych, wypłacanie zaoszczędzonych kwot, organizowanie odczytów, pogadanek oraz imprez, propagujących idę oszczędzania. W szkole działała jedna kasa oszczędności. Uczniom pozostawiono całkowitą swobodę przynależności do tej organizacji. Jej członkiem mógł zostać każdy uczeń i uczennica szkoły oraz wszystkie organizacje szkolne. W szkole powszechnej kasę oszczędności prowadził opiekun przy współudziale swego zastępcy. Opiekuna i zastępcę wyznaczał dyrektora szkoły spośród grona pedagogicznego przy pomocy zarządu SKO. Do zakresu czynności opiekuna należało prowadzenie propagandy i krzewienie akcji oszczędności, wystawianie członkom SKO imiennych szkolnych książeczek oszczędności, przyjmowanie wkładów zebranych przez zarząd, prowadzenie rachunkowości i prac związanych z działalnością SKO, sprawowanie nadzoru nad zarządem, udział w walnych zebraniach, administrowanie funduszem SKO oraz przedkładanie sprawozdań kierownikowi szkoły i instytucji oszczędnościowej, na której SKO się opierała ${ }^{22}$.

Poza opiekunem władzami SKO były: walne zebranie członków, zarząd i komisja rewizyjna, dla których statut określił skład i zakres obowiązków. Odsetki dopisane do zbiorczej książeczki wkładów przez instytucję oszczędnościową stanowiły fundusz SKO, do którego zaliczano także kwoty pobierane przy wystawianiu duplikatu książeczki oraz nie podjęte wkłady i środki uzyskane ze zbiórek, ofiar itp. Zgodnie ze wskazaniami walnego zebrania fundusz SKO mógł być rozdysponowany na wycieczki krajoznawcze, zapomogi dla uczniów, dożywianie, pomoce naukowe i inne potrzeby ${ }^{23}$. Ruch spółdzielczy zachęcał, żeby z samą czynnością oszczędzania połączyć idee samopomocy koleżeńskiej, polegającą na przeznaczeniu części funduszu SKO na wzajemną pomoc, która rozwijała i dawała poczucie solidaryzmu, bezinteresowności i koleżeństwa ${ }^{24}$.

W szkolnictwie średnim i zawodowym szkolną kasę oszczędności prowadził zarząd, który realizował podobne zadania do opiekuna SKO w szkołach powszechnych ${ }^{25}$. Pozostałe zasady funkcjonowania SKO, takie jak: zasady działalności walnego zgromadzenia, komisji rewizyjnej, warunki oszczędzania i podejmowania wkładów, tworzenia i podziału funduszu SKO były podobne, jak w przypadku szkolnych kas oszczędności, działających na ternie szkół powszechnych. Do obowiązków zarządu SKO należała propaganda idei oszczędności w całym społeczeństwie, a przede wszystkim w domu rodzinnym. Zarząd nie tylko organizował zebrania, wygłaszał pogadanki, odczyty, organizował przedstawienia szkolne, przewodniczył też w organizowaniu Międzynarodowego Dnia Oszczędności.

\footnotetext{
22 Statut szkolnej Kasy Oszczędności dla szkót powszechnych, „Dz.U. MWRiOP” 1935, nr 1, s. 6-7

${ }^{23}$ Ibidem.

24 J. Dominko, Idea oszczędności a młodziė,, „Społem” 1935, nr 20, s. 22-23; F. Mróz, Jak u nas zakładano szkolne kasy oszczędności, „Czasopismo Spółdzielni Rolniczych” 1927, nr 1, s. 7-8.

${ }_{25}$ Statut Szkolnej Kasy Oszczędności dla szkót średnich ogólnokształcących i zawodowych wszelkich stop$n i$, ,Dz.U. MWRiOP” 1935, nr 1, s. 8-9.
} 
W okresie międzywojennym były znane trzy systemy prowadzenia szkolnych kas oszczędności: znaczkowy, kombinowany i gotówkowy; czwartym systemem był system skarbonkowy ${ }^{26}$. System znaczkowy najbardziej znany i - jak pisano - najmniej praktyczny, polegał na sprzedaży dzieciom kolorowych znaczków 5-10- i 50-groszowych, które uczeń naklejał na blankiet ze swoim nazwiskiem. Zaklejony znaczkami cały blankiet oddawał nauczycielowi, który wybierał pieniądze wychowanka złożone na wspólnej klasowej lub szkolnej książeczce oszczędnościowej i składał je do kasy publicznej na imienną książeczkę tego ucznia, który oddał zapełniony znaczkami blankiecik. Taki uczeń miał już swoją własną książeczkę kasową tej instytucji oszczędnościowej, w której były lokowane oszczędności szkolne. Otrzymywał nowy blankiet do naklejania znaczków, po zapełnieniu którego jego środki finansowe były wpłacane na już wystawioną imienną książeczkę. ${ }^{27}$

System znaczkowy miał swoje zalety i wady. Był praktyczny w propagandzie oszczędności, ponieważ kolorowe znaczki cieszyły się zainteresowaniem dzieci, ale należało wcześniej wyłożyć pieniądze na ich zakup. Najważniejszą niedogodnością systemu znaczkowego był brak prowadzenia zapisów kasowych. Dziecko w każdej chwili mogło zgubić blankiet ze znaczkami, w związku z tym trudno było dojść do tego, ile oszczędności mieli poszczególni uczniowie. Taka praktyka wpłynęła na zahamowanie rozwoju szkolnych kas oszczędności, zniechęcając wychowawców. Wielu z nich zaczęło równolegle ze sprzedażą znaczków prowadzić notatki o oszczędnościach każdego dziecka, które okazały się być bardzo przydatne, dawały bowiem ogólny ogląd statystyczny w oszczędzaniu poszczególnych uczniów, klas i szkół. W ten sposób powstał system kombinowany, który był bardziej czytelny od systemu znaczkowego ${ }^{28}$.

Praktycznym i zalecanym systemem prowadzenia szkolnej kasy oszczędności był system gotówkowy, polegający na założeniu każdemu dziecku imiennej szkolnej książeczki oszczędnościowej (blankiet oszczędnościowy), w której były dokonywane wpisy każdej jego wpłaty i wypłaty. Ponadto dla każdej klasy był założony dziennik kasowy, w którym każdy uczeń miał swoje konto (jedną stronę dziennika kasowego), na którym były zapisywane wszystkie operacje finansowe ucznia. Należało prowadzić wykazy kasowe dla poszczególnych klas i całej szkoły ${ }^{29}$.

\footnotetext{
26 „Młody Spółdzielca” 1936, nr 2 (7), s. 15.

27 P. Letniowski, O systemach prowadzenia szkolnych kas oszczędności, „Praca Szkolna” 1932, nr 1, s. 25; Kasy oszczędności dziatwy i młodzieży, s. 35-38.

28 S. E. Bońkowski, Szkolna Kasa Oszczędności, Warszawa 1926, s. 44-73.

${ }^{29}$ Ibidem, s. 26-27; Kasy oszczędności dziatwy i młodzieży, s. 27-35.
} 
Tabela. Statystyka szkolnych kas oszczędności opartych na Pocztowej Kasie Oszczędności w szkolnictwie powszechnym w latach 1937-1939

\begin{tabular}{|c|c|c|c|c|c|c|c|}
\hline Lp. & $\begin{array}{l}\text { Okręgi } \\
\text { szkolne }\end{array}$ & $\begin{array}{c}\text { Liczba } \\
\text { SKO. Stan } \\
\text { na 1 VI } \\
1937\end{array}$ & $\begin{array}{l}\text { Procent } \\
\text { SKO do } \\
\text { liczby } \\
\text { szkół na } \\
\text { 1 VI } 1937\end{array}$ & $\begin{array}{c}\text { Liczba } \\
\text { SKO. } \\
\text { Stan na } 1 . \\
\text { II. } \\
1938\end{array}$ & $\begin{array}{c}\text { Procent } \\
\text { SKO do } \\
\text { liczby } \\
\text { szkół } \\
\text { na } 1 \text { II } \\
1938\end{array}$ & $\begin{array}{c}\text { Liczba } \\
\text { SKO. } \\
\text { Stan na } \\
\text { 1 V } 1939\end{array}$ & $\begin{array}{c}\text { Procent } \\
\text { SKO do } \\
\text { liczby } \\
\text { szkół } \\
\text { na } 1 \mathrm{~V} \\
1939\end{array}$ \\
\hline 1. & Lubelski & 1314 & 54,7 & 1372 & 58,8 & 1259 & 62,5 \\
\hline 2. & Brzeski & 1202 & 52,1 & 1308 & 54,4 & 1566 & 76,3 \\
\hline 3. & Wileński & 1612 & 44,9 & 1744 & 49,2 & 1875 & 52,3 \\
\hline 4. & Krakowski & 1938 & 43,6 & 1975 & 48,0 & 2055 & 51,6 \\
\hline 5. & Warszawski & 2206 & 42,2 & 2259 & 48,7 & 2609 & 55,7 \\
\hline 6. & Śląski & 288 & 37,4 & 280 & 41,2 & 377 & 45,3 \\
\hline 7. & Łucki & 595 & 30,1 & - & - & - & - \\
\hline 8. & Poznański & 1048 & 25,4 & 641 & 27,7 & 795 & 31,7 \\
\hline 9. & Lwowski & 1303 & 24,2 & 1372 & 27,1 & 1553 & 30,1 \\
\hline 10. & Pomorski & - & - & 398 & 29,0 & 624 & 30,0 \\
\hline \multirow[t]{2}{*}{11} & Wołyński & - & - & 687 & 34,4 & 815 & 38,5 \\
\hline & Razem & 11506 & $38,0 \%$ & 12036 & 42,3 & 13551 & 46,6 \\
\hline
\end{tabular}

Źródło: „Dz.U. KOS Poznańskiego” 1937, nr 6, s. 140; „Dz.U. KOS Wołyńskiego” 1938, nr 3, s. 51; „Dz.U. KOS Wołyńskiego” 1939, nr 6, s. 176.

Tabela przedstawia dynamikę rozwoju szkolnych kas oszczędności w szkolnictwie powszechnym w ostatnich trzech latach okresu międzywojennego. Dokonując jej analizy, można stwierdzić, że co roku wzrastała liczba kas oszczędności zakładanych w szkołach powszechnych. W pierwszej połowie 1939 r. działało ponad 13,5 tys. szkolnych kas oszczędności, co oznacza, że organizacje te funkcjonowały w 46,6\% szkół powszechnych $^{30}$. Poza tym 676 szkolnych kas oszczędności pracowało na terenie szkolnictwa średniego ${ }^{31}$. W 1938 r. na łamach „Młodego Obywatela” pisano, że szkolne kasy oszczędności jednoczą we wspólnej pracy oszczędnościowej przeszło milion członków spośród młodzieży $i$ dziatwy szkolnej ${ }^{32}$. Zaprezentowane dane wskazują na fakt, że szkolne kasy

30 „Dz.U. KOS Poznańskiego” 1937, nr 6, s. 140; „Dz.U. KOS Wołyńskiego” 1938, nr 3, s. 51; „Dz.U. KOS Wołyńskiego" 1939, nr 6, s. 176.

31 „Dz.U. KOS Wołyńskiego” 1938, nr 3, s. 51; „Dz.U. KOS Wołyńskiego” 1939, nr 6, s. 176.

32 Idziemy na przód, „Młody Obywatel” 1938, nr 6-7, s. 7. 
oszczędności można uznać za popularne organizacje uczniowskie w systemie szkolnym II Rzeczypospolitej.

Intensywny rozwój szkolnych kas oszczędności rozpoczął się od 1927 r. Do 1935 r. organizacje te działały na zasadach spółdzielczych. Od 1935 r. zostały objęte patronatem Pocztowej Kasy Oszczędności (PKO), którą zlikwidowano w 1947 r. W jej miejsce utworzono Powszechną Kasę Oszczędności Bank Państwowy, którego patronat nad szkolnymi kasami oszczędności trwa do dziś i jest statutowym obowiązkiem tego banku. Zatem doświadczenia międzywojenne w zakresie organizowania szkolnych kas oszczędności były kontynuowane po II wojnie światowej i nadal są realizowane we współczesnej rzeczywistości oświatowo-wychowawczej. „Projekt Szkolnych Kas Oszczędności, którego korzenie sięgają lat dwudziestych ubiegłego stulecia, jest aktywnie rozwijającym się programem o ogromnym potencjale edukacyjnym. Kierunki jego rozwoju są wyznaczane przez kolejne pokolenia uczniów, którzy, czerpiąc z niego praktyczną wiedzę o finansach i ekonomii, zyskują niezbędne narzędzia do radzenia sobie w dorosłym życiu" - czytamy na stronie internetowej PKO Banku Polskiego ${ }^{33}$.

\section{Bibliografia}

AAN, zespół: SIN, sygn. 11.

Bolechowicz R., Refleksje na temat kas oszczędności uczniów, „Znicz” II, 21.

Bońkowski S. E., Szkolna Kasa Oszczędności, Warszawa 1926.

Czechowicz J., Oszczędność - drogą do niezależności gospodarczej Polski, „Praca Szkolna” 1933/4, nr 2.

Długokęcki J., Jak zakładać i prowadzić szkolne kasy oszczędności, Warszawa 1931.

Dominko J., Idea oszczędności a młodzież, „Społem” 1935, nr 20.

Dominko J., Oszczędzaj mądrze, „Młody Spółdzielca” 1936, nr 2 (7).

„Dz.U. KOS Brzeskiego” 1926, nr 9.

„Dz.U. KOS Brzeskiego” 1928, nr 7.

„Dz.U. KOS Krakowskiego” 1935, nr 1-2.

„Dz.U. KOS Łódzkiego” 1930, nr 9.

„Dz.U. KOS Pomorskiego” 1933, nr 2, nr 3.

„Dz.U. KOS Poznańskiego” 1935, nr 2.

„Dz.U. KOS Poznańskiego” 1937, nr 6.

„Dz.U. KOS Warszawskiego” 1935, nr 3-4.

„Dz.U. KOS Wileńskiego” 1933, nr 4.

„Dz.U. KOS Wołyńskiego” 1926, nr 5-6.

„Dz.U. KOS Wołyńskiego” 1934, nr 10.

„Dz.U. KOS Wołyńskiego” 1938, nr 3

„Dz.U. KOS Wołyńskiego” 1939, nr 6.

„Dz.U. MWRiOP” 1925, nr 15.

„Dz.U. Wydziału Oświecenia Publicznego Województwa Śląskiego” 1925, nr 11.

„Dz.U. Wydziału Oświecenia Publicznego Województwa Śląskiego” 1927, nr 2.

„Młody Spółdzielca” 1936, nr 2 (7), s. 15.

\footnotetext{
${ }^{33}$ https://www.pkobp.pl/uczniowie-i-studenci/szkolne-kasy-oszczednosci/historia/
} 
https://www.pkobp.pl/uczniowie-i-studenci/szkolne-kasy-oszczednosci/historia/

Idziemy na przód, „Młody Obywatel” 1938, nr 6-7.

Jak oszczędza młodzież w Polsce, „Gazetka Oszczędnościowa” 1932, nr 1.

Jałomin S., Szkolne kasy oszczędności, Kraków 1909.

Jaromin S., Szkolne kasy oszczędności w Krakowie, „Muzeum” 1910, nr 1.

Kopia H., Kasa oszczędności uczniów w gimnazjum sokalskim, „Muzeum” 1915, nr 1 i nr 2. Okólnik c. k. Rady Szkolnej Krajowej w sprawie szkolnych kas oszczędności, „Czasopismo dla Spółek Rolniczych" 1911, nr 10.

Kułak F., Szkolne Kasy Oszczędności w okręgu spółki oszczędnościowej i pożyczkowej w Kuszynie, „Czasopismo dla Spółek Rolniczych” 1910, nr 2.

Lenartowicz R., Martwy a żywy pieniadz, Katowice 1932.

Letniowski P., O systemach prowadzenia szkolnych kas oszczędności, „Praca Szkolna” 1932, nr 1.

Majewski J., Jaki system szkolnej kasy oszczędności byt najodpowiedniejszy, „Czasopismo Pedagogiczne" 1913, nr 3.

Malarz A., Jak osiagnać dobrobyt, Katowice-Warszawa 1931.

Małkowicz J. ks, O oszczędności, Warszawa1934.

Mandel S., Szkolne Kasy Oszczędności jako czynnik społeczno-wychowawczy, Lwów 1913.

Mróz F., Jak u nas zakładano szkolne kasy oszczędności, „Czasopismo Spółdzielni Rolniczych” 1927, nr 1 .

Okólnik Kuratora Okręgu Szkolnego Pomorskiego M. Pollaka z 12 stycznia 1932 roku w sprawie propagandy oszczędności w szkołach, „Dz.U. KOS Pomorskiego” 1932, nr 1.

Okólnik Kuratorium Okręgu Szkolnego Łódzkiego w sprawie szkolnych kas oszczędności, „Dz.U. KOS Łódzkiego" 1931, nr 5.

Okólnik Kuratorium Okręgu Szkolnego Wolyńskiego w sprawie propagandy PKO w szkołach na rzecz idei oszczędności, „Dz.U. KOS Wołyńskiego” 1928, nr 8.

Okólnik Ministra WRiOP K. Bartla z dnia 8 stycznia 1927 roku, „Dz.U. MWRiOP” 1927, nr 3.

Okólnik Ministra WRiOP S. Czerwińskiego z 24 kwietnia 1930 roku w sprawie Szkolnych Kas Oszczędności, „Dz.U. MWRiOP” 1930, nr 5.

Okólnik Ministra WRiOP S. Czerwińskiego z 24 kwietnia 1930 roku w sprawie Szkolnych Kas Oszczędności s. 222-223;

Okólnik Ministra WRiOP S. Czerwińskiego z 3 września i z dnia 18 września 1928 roku, „Dz.U. KOS Łódzkiego" 1928, nr 9.

Okólnik Ministra WRiOP Wacława Jędrzejewicza z dnia 14 stycznia 1935 roku w sprawie Szkolnych Kas Oszczędności, „Dz.U. MWRiOP” 1935, nr 1, s. 4.

Pomóżmy sobie w biedzie, „Młody Spółdzielca” 1936, nr 2 (7).

Pouczenia o prowadzeniu groszowych kas oszczędności (dla młodzieży, shużby domowej, gospodarczej, robotników i licznych rzesz ubogiej ludności), „Czasopismo dla Spółek Rolniczych” 1911, nr 2.

Propaganda Pocztowej Kasy Oszczędności w szkołach na rzecz idei oszczędności, „Dz.U. KOS Poznańskiego" 1928, nr 12.

Statut Szkolnej Kasy Oszczędności dla szkót powszechnych, „Dz.U. MWRiOP” 1935, nr 1.

Statut Szkolnej Kasy Oszczędności dla szkót średnich ogólnokształcących i zawodowych wszelkich stopni, „Dz.U. MWRiOP” 1935, nr 1.

Szkolne kasy oszczędności, „Czasopismo dla Spółek Rolniczych” 1911, nr 2.

Szkolne Kasy Oszczędności, „Głos Nauczycielski” 1934, nr 1.

Szyc S., O wartości szkolnych kas oszczędności, „Rodzina i Szkoła” 1912, nr 3.

Twarecki L., Spółdzielcze wychowanie młodzieży przez Szkolne Kasy Oszczędności, Lwów 1925.

Umieć oszczędzać - to sztuka, „Młody Spółdzielca” 1937, nr 2 (8), s. 2.

Wskazania wychowawcze zawarte w rozporządzeniach i okólnikach Ministerstwa Wyznań Religijnych i Oświecenia Publicznego, zebrał F. Śliwiński, Łódź 1935.

Załuski P., Jak zakładać i prowadzić Szkolne Kasy Oszczędności, Warszawa 1926. 
